\title{
MAXIMIZING THE EFFECIENCY OF COMPOST RICE STRAW FOR POTATO PRODUCTION
}

Taha, A. A,; * G, A. Baddour ; ${ }^{*}$ A. A. Mosa; ${ }^{*}$ and Shahd, A. Awadine*

"Soils Dept.- Fac. of Agriculture- Mansoura Univ.- Egypt

** Soil, Water and Environ. Ins. Agric. Research Center- Giza- Egypt.

\section{ABSTRACT}

The present study is carried out under field conditions on a clay soil at the Experimental Farm of the Faculty of Agric. Mansoura Univ. during the winter season of 2012/2013 to study the combined effect of compost rice straw and bio fertilizers in the presence of ( Indole acetic acid ,Fulvic acid , and Gibberellic acid) as foliar amendments on plant growth and tuber yield and quality of potato (Solanum tuberosum, L.) as well as chlorophyll content in the leaves, N, P and K concentrations in the leaves and tubers in addition to starch, Total soluble solids and nitrate content in tubers. Nine treatments were arranged in complete randomized block design with 3 replicates as follows; 1- Compost rice straw (CRS), 2- (CRS) + Indole acetic acid (IAA), 3- CRS+ Fulvic acid (F.A) , 4- CRS + Gibberellic acid (G.A). 5- (CRS) + Mixture of Azotobacter chrococcum and Bacillus circulans (Mix), 6- (CRS) + (Mix) + (IAA), 7$(\mathrm{CRS})+(\mathrm{Mix})+(\mathrm{F} . \mathrm{A}), 8-(\mathrm{CRS})+(\mathrm{Mix})+(\mathrm{G} . \mathrm{A})$. Also, the recommended doses of $\mathrm{N}$ $\mathrm{P}$ and $\mathrm{K}$ fertilizers for potato were put in consideration as a control treatment. Thus, the total numbers of treatment are 9 treatments.

The obtained results can be summarized as follow:

- Spraying of foliar amendments either in a single form or in combination with bio fertilization led to a positive effect on the growth and yield of potato tuber.

- Fulvic acid were more effective for all the studied traits than other foliar amendments.

- $\quad$ The highest level of nitrate and trace elements were detected in potato tubers produced from the plants treated with the recommended of $\mathrm{N}, \mathrm{P}$ and $\mathrm{K}$ fertilizers (control). While the lowest level produced from plants treated with fulvic acid+ the mix of bio fertilizers + CRS.

- Inoculation of potato tubers with the mixture of multi strains inoculants in combination with the studied foliar amendments and CRS gave a higher magnitude of plant growth, chemical composition, yield and its components as well as quality parameters of potato tuber.

- The results ensure the importance of partial replacement of chemical NPK fertilizers by the use of bio and organic ones in producing potatoes. Its application would reduce the consumption of chemical fertilizers which in turn reduce the production costs as well as decrease nitrate content in the tubers besides, saving the environment from chemical pollution.

Keywords: compost rice straw (CRS), bio fertilizer, Fulvic acid, Gibberellic acid, Indole acetic acid, Potato

\section{INTRODUCTION}

Potato (Solanum tuberosum L.) is one of the most important vegetables in Egypt. It gained a considerable importance as an export crop to European markets and one of the national income resources. Nutritional requirements of potato crop are quite high and the application of chemical fertilizers is considered essential to obtain high tuber yields. Intensive use of chemical fertilizers led to increase the pollution in soil, water and food. The progressive rise in the cost of these fertilizers and their relative low efficiency, 
particularly in developing countries such as Egypt, give an account for finding out a partial or full substitution for the usual classic applied chemical fertilizers. Organic fertilizers are potential substitutes for such chemical fertilizers ( Mansour 2012 and Baddour 2014).

In Egypt, rice straw is considered one of the main agricultural wastes which represent about 4 million tons annually produced every autumn. Rice straw is commonly burnt in many of the developing countries. Burning rice straw has harmful environmental implications through global addition of carbon dioxide, a gas contributing to the greenhouse effect, and likely high health costs through increase in respiratory problems in the local population. The conversion of rice straw into value-adde compost may have the potential to improve productivity of the crops and reduce environmental pollution (ElAgamy 2006 and Moursy, 2013).

Organic fertilization is very important not only for providing the plants with Their nutritional requirements without having any undesirable impacts on the environment but also for improving physical, chemical and biological properties of the soil.

Gibberellic acid is a plant growth regulator of economic and industrial importance Phytohormones, mainly including auxins, gibberellins, and Indole acetic acid soaking application of tubers in mixture of GA3+IAA before planting was very effective on the plant start at 21 and 28 day after planting, increase vegetative growth parameters, improved tubers quality, tubers yield and its components as compared to the control and other treatment (Aksenova et al., 2009 and Waghmode et al., 2010).

Fulvic acid are a heterogeneous mixture of naturally occurring organic materials that arise from the decay of plant and animal residues. These organic materials contain carbon, which serves as a food source for soil organisms such as bacteria, algae, fungi, and earthworms. These soil organisms break the chemical bonds in the residues as they digest the carbon.Fulvic acid increased water and nutrient holding capacity, increased reserve of slow release nutrients, enhanced solubility of phosphorus, zinc, iron, manganese, and copper, increased resistance to soil $\mathrm{pH}$ change, increased soil warmth, improved soil aggregation, decreased erosion, enlarged root system and increased stimulation of plant growth due to hormones.

Biofertilizers (Azotobacter chroccocum, Bacillus circulans and Bacillus megatherium ) play an important role in enhancing crop productivity through nitrogen fixation, phosphate and potassium solubilization, plant hormones production, ammonia excretion, siderophores formation and to control various plant diseases ( Shalaan, 2005 and Mirzakhani et al., 2009).

The objective of this investigation is to determine the effect of Fulvic acid, Gibberellic acid and Indole acetic acid in the presence and absence of biofertilization on the efficiency of compost rice straw for realizing the highest safe yield of potato tuber (Solanum tuberosum L.) sponta s.p.

\section{MATERIALS AND METHODS}

A field experiment was undertaken at the Experimental Farm of Faculty of Agric. Mansoura Univ. during the winter season of 2012/2013 field 
experiment to investigate the various combinations among organic manures, growth regulators and biofertilizers on the production of safe and economic potato tuber.

Eight treatments were arranged in a complete a randomize block design with 3 replicates as follows; ; 1- Compost rice straw (CRS), 2- (CRS) + Indole acetic acid (IAA), 3- CRS+ Fulvic acid (F.A) , 4- CRS + Gibberellic acid (G.A). 5- (CRS) + Mixture of Azotobacter chrococcum and Bacillus circulans (Mix), 6- (CRS) + (Mix) + (IAA), 7- (CRS) + (Mix) + (F.A), 8- (CRS) + $(\mathrm{Mix})+(\mathrm{G} . \mathrm{A})$. Also, the recommended doses of $\mathrm{N}, \mathrm{P}$ and $\mathrm{K}$ fertilizers for potato were put in consideration as a control treatment. Thus, the total numbers of treatments were 9 .

Composite soil sample was collected from the experimental site before planting and analyzed for some physical and chemical properties as shown in Table 1.

Table 1: Some physical and chemical properties of the experimental soil

\begin{tabular}{|c|c|c|}
\hline \multicolumn{2}{|c|}{ Soil properties } & Values \\
\hline \multicolumn{3}{|c|}{ Soil physical properties } \\
\hline \multirow{4}{*}{$\begin{array}{l}\text { Particle size } \\
\text { distribution }\end{array}$} & Sand & $23.63 \%$ \\
\hline & Silt & $29.75 \%$ \\
\hline & Clay & $46.62 \%$ \\
\hline & Soil texture & Clay \\
\hline \multicolumn{2}{|c|}{$\mathrm{EC} \mathrm{dSm}{ }^{-1}$} & 3.16 \\
\hline \multicolumn{2}{|c|}{$\mathrm{PH}$} & 7.88 \\
\hline \multicolumn{2}{|c|}{ Organic matter (\%) } & 1.34 \\
\hline \multicolumn{2}{|c|}{ Calcium carbonate, $\%$} & 3.16 \\
\hline \multirow{4}{*}{$\begin{array}{l}\text { Soluble cations } \\
\text { (meq/100g soil) }\end{array}$} & $\mathrm{Ca}^{++}$ & 5.75 \\
\hline & $\mathrm{Mg}^{++}$ & 3.66 \\
\hline & $\mathrm{Na}^{+}$ & 9.29 \\
\hline & $\mathrm{K}^{+}$ & 0.26 \\
\hline \multirow{4}{*}{$\begin{array}{l}\text { Soluble anions } \\
(\mathrm{meq} / 100 \mathrm{~g} \text { soil) }\end{array}$} & $\mathrm{CO}_{3}{ }^{--}$ & n.d \\
\hline & $\mathrm{HCO}_{3}^{-}$ & 5.97 \\
\hline & $\mathrm{Cl}^{-}$ & 8.61 \\
\hline & $\mathrm{SO}_{4}$ & 4.38 \\
\hline \multirow{3}{*}{$\begin{array}{l}\text { Available nutrients } \\
(\mathrm{mg} / \mathrm{kg})\end{array}$} & Nitrogen & 46.2 \\
\hline & Phosphorus & 5.13 \\
\hline & Potassium & 215 \\
\hline \multirow{7}{*}{$\begin{array}{l}\text { Available micro nutrients } \\
(\mathrm{mg} / \mathrm{kg})\end{array}$} & $\mathrm{Zn}$ & 0.89 \\
\hline & $\mathrm{Fe}$ & 5.18 \\
\hline & $\mathrm{Mn}$ & 3.11 \\
\hline & $\mathrm{Cu}$ & 0.24 \\
\hline & $\mathrm{Pb}$ & 2.79 \\
\hline & $\mathrm{Ni}$ & 1.16 \\
\hline & $\mathrm{Cd}$ & 0.43 \\
\hline
\end{tabular}

EC was determined in soil paste extract.

${ }^{\mathrm{pH}}$ was determined in soil suspension.

Available concentrations of $\mathrm{N}, \mathrm{P}$ and $\mathrm{K}$ were extracted and determined according to the methods described by Hesse (1971). Available $\mathrm{Fe}, \mathrm{Zn}, \mathrm{Mn}, \mathrm{Cu}, \mathrm{Pb}, \mathrm{Ni}$ and $\mathrm{Cd}$ were extracted using DTPA and determined using atomic absorption spectrophotometer according to Chapman and Pratt (1982). 
Compost rice straw (CRS) was prepared in the site of the experiment as follows; the straw was chopped into $5 \mathrm{~cm}$ long pieces, piled, moistened with water and composted in association with a chemical accelerator $(7 \mathrm{~kg}$ super phosphate and $40 \mathrm{~kg}$ ammonium sulphate per ton dry matter, $100 \mathrm{~kg}$ fertile soil per ton dry matter and $10 \%$ FYM). At the initial stage of composting, the EM suspension was sprayed on the raw material amounted 10 liters/ton. During composting (3 months), materials were manually mixed at a week intervals to provide aeration. The moisture content during the composting course was kept at a proper level (60\% by weight) throughout irrigation (El-Hamady et al. 2003). Chemical analysis of the compost rice straw used were presented in Table 2.

Table 2: Some chemical properties of the compost rice straw.

\begin{tabular}{|c|c|}
\hline Parameters O.M. Sources & $\begin{array}{c}\text { Compost rice straw } \\
\text { (CRS) }\end{array}$ \\
\hline Wight of $\mathrm{m}^{3}(\mathrm{~kg})$ & 340 \\
\hline T.Nitrogen (\%) & 1.55 \\
\hline $\mathrm{pH}($ extract 1:5) & 6.09 \\
\hline $\mathrm{EC}_{\mathrm{e}}(1: 10$ water suspension $) \mathrm{dSm}^{-1}$ & 3.82 \\
\hline Organic matter (\%) & 36.29 \\
\hline Organic carbon (\%) & 21.05 \\
\hline $\mathrm{C} / \mathrm{N}$ ratio & 13.6 \\
\hline \multicolumn{2}{|c|}{ Macro nutrients (\%) } \\
\hline $\mathrm{N}$ & 1.55 \\
\hline $\mathrm{P}$ & 0.61 \\
\hline K & 0.97 \\
\hline \multicolumn{2}{|c|}{ Micro nutrients $\left(\mathrm{mg} \mathrm{kg}^{-1}\right)$} \\
\hline $\mathrm{Fe}$ & 55.2 \\
\hline $\mathrm{Mn}$ & 13.9 \\
\hline $\mathrm{Zn}$ & 18.5 \\
\hline $\mathrm{Cu}$ & 3.6 \\
\hline $\mathrm{Pb}$ & 3.44 \\
\hline $\mathrm{Ni}$ & 0.98 \\
\hline Cd & 0.61 \\
\hline
\end{tabular}

Compost rice straw (CRS) was added to the soil before transplanting in a single application at rate of $15 \mathrm{~m}^{3} \mathrm{fed}^{-1}$. Each experimental plot was mixed with CRS and irrigated up to saturation percentages. Then, plots were left for two weeks to elucidate the damage on seedlings and their roots resulted from the heat of decomposition.

Indole acetic acid, fulvic acid, and gibberellic acid were obtained from Egyptian Fertilizer Development Center, El-Mansoura. Foliar amendments were used at rates of $100 \mathrm{ppm}, 4 \mathrm{~g} / \mathrm{L}$ and $100 \mathrm{ppm}$, for Indole acetic acid, fulvic acid, and gibberellic acid, respectively. Each of them was used as a foliar spray 3 times; 35,45 and 55 days after cultivation.

Cell suspension of Azotobacter chroccoccum (AZ), and Bacillus circulans (KSB) were kindly provided from the unit of Biofertilizers, Fac. Agric. Ain shams Univ. Egypt. A mixture of them was proposed at equal parts $\left(10^{8}\right.$ $\mathrm{CFU})$. Potato tubers were treated with the liquid suspension of this mixture as 
soaking before cultivation. Also, the mixture was applied at a rate of $10 \mathrm{ml}$ per seedling 3 times after 15 days of cultivation with 7 days intervals.

Control treatment was treated with 120,75 and $96 \mathrm{~kg} \mathrm{fed}^{-1}$ as a recommended doses of $\mathrm{N}, \mathrm{P}$ and $\mathrm{K}$ for potato plant in the forms of ammonium sulfate $(20.5 \% \mathrm{~N})$, super phosphate $\left(15 \% \mathrm{P}_{2} \mathrm{O}_{5}\right)$ and potassium sulfate $(48$ $\% \mathrm{~K}_{2} \mathrm{O}$ ). Full dose of $\mathrm{P}$ was added to the soil before sowing while; $\mathrm{N}$ and $\mathrm{K}$ were added in two equal doses, one after 15 days from sowing and the other two weeks later.

Potato tuberes (Solanum tuberosum L.) sponta s.p, were planted in October 23th 2012.After 60 days from cultivation, samples of 5 potato tubers were taken randomly from each experimental plot for investigation plant growth parameters were recorded i.e., plant length $(\mathrm{cm})$, number of leaves per plant, fresh and dry weight of whole plant $\left(\mathrm{g} \mathrm{plant}^{-1}\right)$. At harvesting stage (130 days from cultivation) the total tuber yield were weighed and yield component as average fresh and dry weight of bulbs $\left(\mathrm{g} \mathrm{plant}^{-1}\right)$. Finally the total yield (ton fed $^{-1}$ ) was calculated. Potato tuber samples from each experimental plot were taken for elemental analysis, where N,P and $\mathrm{K}$ elements in the dry matter of tuber tissue were determined according to the methods of Peters et al., (2003), Jackson (1973) and Black (1965), respectively. $\mathrm{Fe}, \mathrm{Zn}, \mathrm{Mn}, \mathrm{Cd}, \mathrm{Ni}$ and $\mathrm{Pb}$ concentrations were determined using atomic absorption spectrophotometer; model $1100 \mathrm{~B}$ as described by Chapman and Pratt (1982). For determination nutritional values of potato tubers, total carbohydrates, starch, and nitrate contents were estimated according to the methods of Hedge and Hofreiter (1962), Sadasivam and Manickam, (1996), (A.O.A.C.; 1990), and Singh (1988),respectively.

Leaves samples were extracted in $80 \%$ acetone and the absorption at $663 \mathrm{~nm}$ and $645 \mathrm{~nm}$ are read in spectrophotometer. The amount of chlorophyll is calculated as:

$\mathrm{mg}$ chlorophyll a/g tissues $=12.7\left(\mathrm{~A}_{663}\right)-2.69\left(\mathrm{~A}_{645}\right) \times(\mathrm{v} /(1000 \times \mathrm{w})$

$\mathrm{mg}$ chlorophyll $\mathrm{b} / \mathrm{g}$ tissues $=22.9\left(\mathrm{~A}_{645}\right)-4.68\left(\mathrm{~A}_{663}\right) \times(\mathrm{v} /(1000 \times \mathrm{w})$

where $A=$ absorbance at specific wave length.

$\mathrm{V}=$ final volume of chlorophyll extracted in $80 \%$ acetone.

$\mathrm{W}=$ fresh weight of tissues extracted (Sadasivam and Manickam,1996).

The obtained data were statistically analyzed according to the method described by Gomez and Gomez; 1984.

\section{RESULTS}

\section{A- Plant growth parameters}

Potato plant growth parameters expressed as plant length, average leaves number, fresh and dry weight of whole plant as affected by the application of compost rice straw with or without the application of different growth regulators under study are presented in Table 3.

It could be observed that the application of organic manure, i.e. compost rice straw (CRS) gained less vigor plant growth compared to the application of the recommended doses of N,P and K fertilizers.

Regarding the effect of growth regulators; data in Table (3) revealed that, treating the tuber of potato plant with HS, IAA or GA3 significantly 
increased the mean values of growth parameters under study than those obtained by the untreated tubers. In addition, inoculation of potato tuber by the mixture of multi strains inoculants (Mix) combined with the various organic manures investigated and the different growth regulators gave a more pronounced values for plant growth parameters studied than those obtained for the uninoculated plants. In this respect the highest values were recorded with the plants treated with CRS, HS and inoculated with mixture of microorganisms.

Data of Table 3 showed a significant increases in all parameters under study for the plants treated with any of these growth regulators over that obtained from the untreated plants, In this respect; the highest values ( 88.0, 56.33, 527.9, and 67.3 for No. of tuber per plant, No. of leaves per plant, fresh weight of tuber $(\mathrm{g})$, and dry weight of tuber respectively were realized for the treatment of fulvic acid, while the lowest one $(63.8,46.33$, 393.4, and 55.2) were recorded for CRS treatment for No. of tuber per plant, No. of leaves per plant, fresh weight of tuber $(\mathrm{g})$, and dry weight of tuber, respectively

Table 3; Plant growth parameters of potato tubers as affected by organic manures, foliar amendments and the inoculation with mixture of microorganisms.

\begin{tabular}{|c|c|c|c|c|}
\hline $\begin{array}{l}\text { Char. } \\
\text { Trea. }\end{array}$ & $\begin{array}{l}\text { Plant height } \\
\text { (cm) }\end{array}$ & $\begin{array}{l}\text { No. of leaves } \\
\text { plant }^{-1}\end{array}$ & $\begin{array}{c}\text { F. Wt of foliage } \\
\left(\text { g plant }^{-1}\right)\end{array}$ & $\begin{array}{c}\text { D.Wt of } \\
\text { foliage } \\
\left.\text { (g plant }{ }^{-1}\right)\end{array}$ \\
\hline Control (100\% RD. NPK) & 74.1 & 51.6 & 465.3 & 61.7 \\
\hline C.R.S & 63.8 & 46.33 & 393.4 & 55.2 \\
\hline C.R.S +IAA & 68.3 & 48.7 & 427.2 & 58.9 \\
\hline C.R.S+F.A & 76.9 & 53.1 & 484.7 & 63.4 \\
\hline C.R.S +GA3 & 65.9 & 47.4 & 409.5 & 56.6 \\
\hline C.R.S +Mix & 71.4 & 50.2 & 446.8 & 60.1 \\
\hline C.R.S +Mi+ IAA & 84.5 & 55.5 & 513.4 & 65.8 \\
\hline C.R.S +Mi+F.A & 88.0 & 56.33 & 527.9 & 67.3 \\
\hline C.R.S +Mi+ GA3 & 80.2 & 54.2 & 501.5 & 64.5 \\
\hline L.S.D 5\% & 3.86 & 3.46 & 7.78 & 4.02 \\
\hline
\end{tabular}

\section{C.R.S: compost rice straw}

Mix: mixture of Azotobacter chrococcum, Bacillus circulans
GA3: Gibrellic Acid
IAA: Indol Acetic Acid
F.A: Fulvic Acid

B. chlorophyll and $\mathrm{N}, \mathrm{P}$ and $\mathrm{K}$ content in potato leaves at first stage:

The comparison among the means of the various combined treatments of organic manures, growth regulators and biofertilization as shown in Table 4 has been reflected a significant differences between the average values of chlorophyll $(\mathrm{a}, \mathrm{b} \& \mathrm{a}+\mathrm{b}), \mathrm{N}, \mathrm{P}$ and $\mathrm{K}$ concentrations in the leaves of potato plant after 60 days from sowing.

Regarding the effect of organic manures, data in Table 4 reveal that individual application of CRS significantly decreased the mean values of chlorophyll ( $\mathrm{a}, \mathrm{b}$ \& $\mathrm{a}+\mathrm{b} \mathrm{mg} \mathrm{g}^{-1} \mathrm{~F} . \mathrm{W}$ ) as well as $\mathrm{N}, \mathrm{P}$ and $\mathrm{K}(\%)$ in potato leaves as compared to the control treatment. On other words; the highest values $(0.886,0.543,1.429,3.77,0.495$ and 4.31 for total chlorophyll, $\mathrm{N}, \mathrm{P}$ and $\mathrm{K}$, respectively were realized for the control treatment, while the lowest values $(0.767,0.462,1.229,3.06,0.403$ and 3.48$)$ for such trait were 
obtained from the plants treated with CTR. In this respect, a superiority effect was realized within the foliar application for the plants treated with fulvic acid for all the aforementioned traits following with GA3 and lastly IAA.

Table 4: Effects of organic manures, growth regulators and biofertilizers on chlorophyll content, nitrogen, phosphorus and potassium content after 60 days from sowing in potato plant foliage.

\begin{tabular}{|l|c|c|c|c|c|c|}
\multirow{2}{*}{$\begin{array}{c}\text { Char. } \\
\text { Trea. Leaves }\end{array}$} & \multicolumn{3}{c|}{ Mg/g fw } & \multicolumn{3}{c|}{ \% } \\
\cline { 2 - 7 } & Chlo A & Chlo. B & A+B & N & P & K \\
\hline Control (100\% RD. NPK) & 0.834 & .0503 & 1.337 & 3.45 & 0.452 & 3.89 \\
\hline C.R.S & 0.767 & 0.462 & 1.229 & 3.06 & 0.403 & 3.48 \\
\hline C.R.S +IAA & 0.796 & 0.479 & 1.215 & 3.23 & 0.426 & 3.66 \\
\hline C.R.S+ F.A & 0.855 & 0.514 & 1.369 & 3.54 & 0.466 & 4.01 \\
\hline C.R.S +GA3 & 0.781 & 0.470 & 1.251 & 3.15 & 0.415 & 3.57 \\
\hline C.R.S +Mix & 0.817 & 0.492 & 1.309 & 3.34 & 0.438 & 3.78 \\
\hline C.R.S +Mi+ IAA & 0.875 & 0.534 & 1.409 & 3.69 & 0.484 & 4.19 \\
\hline C.R.S +Mi+ F.A & 0.886 & 0.543 & 1.429 & 3.77 & 0.495 & 4.31 \\
\hline C.R.S +Mi+GA3 & 0.866 & 0.525 & 1.391 & 3.62 & 0.478 & 4.10 \\
\hline L.S.D 5\% & 0.01 & 0.02 & 0.01 & 0.12 & 0.022 & 0.12 \\
\hline
\end{tabular}

\section{C.R.S: compost rice straw}

Mix: mixture of Azotobacter chrococcum, Bacillus circulans

GA3: Gibrellic Acid IAA: Indol Acetic Acid F.A: Fulvic Acid

C. Yield and its components of potato as affected by organic manures, growth regulators and bio-fertilizer

The interaction effects between organic manures, growth regulators and inoculation treatments are shown in Table 5. Results reveal that the most suitable treatment, which realized the highest values of yield and its components comparing with the control treatment, was connected with the plants treated with C.R.S +Mix+ F.A.

Concerning the effect of fulvic acid, indole acetic acid and gibberellic acid as solely form on the mean values of yield and yield components of potato plant; data of Table 5 show a significant increases in all parameters under study for the plants treated with any of these growth regulators over that obtained from the untreated plants, the mean values of such traits more than that obtained from the control treatment. In this respect; the highest values (855.5, 183.6, 17.10 and 20.37) were realized for the treatment of fulvic acid+CRS+Mix, for fresh weight of tuber $(\mathrm{g})$, average tuber weight $(\mathrm{g})$, dry matter $(\%)$ and total tuber yield (ton fed ${ }^{-1}$ ), respectively, and 7.61 for No. of tuber per plant, obtained from the CRS treatment. while the lowest one $(632.8,83.2,83.2,15,82$ and 16.92) were recorded for the untreated plants for fresh weight of tuber $(\mathrm{g})$, average tuber weight $(\mathrm{g})$, dry matter $(\%)$ and total tuber yield $\left(\right.$ ton $\left.\mathrm{fed}^{-1}\right)$, respectively, and 4.66 for No. of tuber per plant, obtained from the C.R.S +Mix F.A treatment.

D. Nutritional content of potato tubers:

Effect of bio fertilization, organic manures and foliar amendments on $\mathrm{N}, \mathrm{P}, \mathrm{K}, \mathrm{Fe}, \mathrm{Zn}$ and $\mathrm{Mn}$ concentration, at harvest stage of potato tuber as well 
as its interaction during second season of the experiment are shown in Table 6.

Regarding the effect of bio fertilization on $\mathrm{N}, \mathrm{P}$ and $\mathrm{K}$ concentration, at harvest stage of potato tubers data in Table 6 indicate that the mean values were significantly increased due to an addition of Azotobacter boinoculants .

As for the combined effect between the previously mentioned treatments, data in Table 6 reveal that the highest mean values $(2.58,0.343$, $3.9212 .09,7.69$ and 4.02)ppm for N,P,K, Fe, Zn and Mn concentration, in potato tuber at harvesting stage obtained from Fulvic acid jointly with compost rice straw in presence of Azotobacter boinoculants Meanwhile the lowest mean values were $1.68,0.225,1.68,3.13,8.89,5.17$ and 2.13 in $\mathrm{N}$, $\mathrm{P}, \mathrm{Fe}, \mathrm{Zn}$ and $\mathrm{Mn}$ concentration, \% obtained from CRS treatment.

Table (5) Yield and its components of potato as affected by organic manures, growth regulators and bio-fertilizer:

\begin{tabular}{|l|c|c|c|c|c|}
\hline $\begin{array}{c}\text { Char. } \\
\text { Trea. }\end{array}$ & $\begin{array}{c}\text { F.W of tuber } \\
\text { (g plant }^{-1} \text { ) }\end{array}$ & $\begin{array}{c}\text { No of } \\
\text { tuber } \\
\text { plant }^{-1}\end{array}$ & $\begin{array}{c}\text { Average } \\
\text { atuber } \\
\text { weight } \\
\mathbf{( g )}\end{array}$ & $\begin{array}{c}\text { D.M of } \\
\text { tuber } \\
\mathbf{( \% )}\end{array}$ & $\begin{array}{c}\text { Total tuber } \\
\text { yield } \\
\text { (Ton fed }^{-1} \text { ) }\end{array}$ \\
\hline Control (100\% RD. NPK) & 743.3 & 6.08 & 122.3 & 16.48 & 18.66 \\
\hline C.R.S & 632.8 & 7.61 & 83.2 & 15.82 & 16.92 \\
\hline C.R.S +IAA & 686.4 & 7.02 & 97.8 & 16.15 & 17.75 \\
\hline C.R.S+ F.A & 771.8 & 5.79 & 133.3 & 16.66 & 19.20 \\
\hline C.R.S +GA3 & 657.9 & 7.40 & 88.9 & 16.01 & 17.38 \\
\hline C.R.S +Mix & 715.2 & 6.45 & 110.1 & 16.34 & 18.24 \\
\hline C.R.S +Mix IAA & 821.3 & 5.03 & 163.3 & 16.95 & 20.05 \\
\hline C.R.S +Mix F.A & 855.5 & 4.66 & 183.6 & 17.10 & 20.37 \\
\hline C.R.S +Mix GA3 & 798.6 & 5.41 & 147.6 & 16.81 & 19.71 \\
\hline L.S.D 5\% & 13.7 & 0.88 & 16.5 & 0.45 & 0.95 \\
\hline
\end{tabular}

C.R.S: compost rice straw

Mix: mixture of Azotobacter chrococcum, Bacillus circulans

GA3: Gibrellic Acid IAA: Indol Acetic Acid F.A: Fulvic Acid

Table 6: Nutritional elements in the tuber of potato as affected by organic manures, foliar application and the inoculation with mixture of microorganisms after harvest:

\begin{tabular}{|l|c|c|c|c|c|c|}
\hline \multirow{2}{*}{$\begin{array}{c}\text { Char. } \\
\text { Trea. Tubers }\end{array}$} & \multicolumn{1}{c|}{$\mathbf{N}$} & $\mathbf{P}$ & $\mathbf{K}$ & $\mathbf{F e}$ & Zn & Mn \\
\cline { 2 - 7 } & \multicolumn{2}{|c|}{$\%$} & & \multicolumn{3}{c|}{ mg kg $^{-1}$} \\
\hline Control (100\% RD. NPK) & 2.11 & 0.288 & 3.53 & 10.58 & 6.36 & 3.11 \\
\hline C.R.S & 1.68 & 0.225 & 3.13 & 8.89 & 5.17 & 2.13 \\
\hline C.R.S +IAA & 1.87 & 0.256 & 3.29 & 9.65 & 5.81 & 2.61 \\
\hline C.R.S+F.A & 2.22 & 0.305 & 3.64 & 11.09 & 6.79 & 3.42 \\
\hline C.R.S +GA3 & 1.79 & 0.239 & 3.21 & 9.27 & 5.46 & 2.35 \\
\hline C.R.S +Mix & 2.01 & 0.271 & 3.42 & 10.04 & 6.12 & 2.86 \\
\hline C.R.S +Mi+ IAA & 2.45 & 0.332 & 3.81 & 11.76 & 7.45 & 3.88 \\
\hline C.R.S +Mi+ F.A & 2.58 & 0.343 & 3.92 & 12.09 & 7.69 & 4.02 \\
\hline C.R.S +Mi+ GA3 & 2.34 & 0.321 & 3.73 & 11.38 & 7.13 & 3.69 \\
\hline L.S.D 5\% & 0.15 & 0.012 & 1.04 & 0.07 & 0.05 & 0.06 \\
\hline
\end{tabular}

C.R.S: compost rice straw

Mix: mixture of Azotobacter chrococcum, Bacillus circulans

GA3: Gibrellic Acid IAA: Indol Acetic Acid F.A: Fulvic Acid 


\section{E- Quality parameters of Potato tuber:}

The mean values of total carbohydrates $\%$, starch $\%$, and nitrate concentration as well as average heavy metal contents $\left(\mathrm{mg} \cdot \mathrm{kg}^{-1}\right)$ found in potato tubers as influenced by compost rice straw, growth regulators with or without the mixture of multi strains inoculants are presented in Table 7.

The mean percentage of total carbohydrates and starch revealed that ; the highest mean values were recorded for the plants treated with CRS + $\mathrm{HS}+\mathrm{Mix}$, while the lowest values were obtained from the CRS treatment. Data in Table 7 also indicated that an addition of HS, IAA or GA3 combined with CRS significantly increase the mean values of the aforementioned traits than those obtained due to an application of the CRS alone. In this respect; the superiority effect was happened due to an addition of F.A addition followed by IAA and lately GA3 Moreover, inoculation of potato tuber with the mixture of microorganisms had a stimulation effect on the contents of total carbohydrates and starch of potato tuber for all the treatments under investigation. On the contrary of this trend, huge amounts of nitrate and trace elements were accumulated in potato tuber due to the addition of mineral fertilizers (control) more than those obtained for the plants treated with different organic sources either in the presence or absence of the various foliar amendments studied. In this respect; the highest mean values; (40.18, $7.41,3.76 \& 1.62) \mathrm{mg} \mathrm{kg}^{-1}$ were recorded for the tubers treated with the recommended doses of $\mathrm{N}, \mathrm{P}$ and $\mathrm{K}$, while the lowest values; 29.36, 5.93, 2.44\& $0.49 \mathrm{mg} \mathrm{kg}^{-1}$ were resulted from the treatment of C.R.S +Mi+ F.A for $\mathrm{NO}_{3}-\mathrm{N}, \mathrm{Pb}, \mathrm{Ni} \& \mathrm{Cd}$, respectively.

Table 7: Quality parameters of potato tuber as affected by organic manures, foliar amendments and the mixture of bio fertilizer comparing with the control treatment

\begin{tabular}{|c|c|c|c|c|c|c|}
\hline \multirow{2}{*}{$\begin{array}{l}\text { Char. } \\
\text { Trea. Tubers }\end{array}$} & $\begin{array}{c}\text { T. } \\
\text { carbohydrates }\end{array}$ & Starch & $\mathrm{NO}_{3}-\mathrm{N}$ & $\mathbf{P b}$ & $\mathrm{Ni}$ & Cd \\
\hline & \multicolumn{2}{|l|}{$\%$} & \multicolumn{4}{|c|}{$\mathrm{mg} \mathrm{kg}^{-1}$} \\
\hline Control (100\% RD. NPK) & 80.98 & 12.29 & 40.18 & 7.41 & 3.76 & 1.62 \\
\hline C.R.S & 79.31 & 10.92 & 36.73 & 7.25 & 2.64 & 0.58 \\
\hline C.R.S + IAA & 80.19 & 11.63 & 34.15 & 6.87 & 3.19 & 1.32 \\
\hline C.R.S+F.A & 81.40 & 12.71 & 30.07 & 6.45 & 2.88 & 1.03 \\
\hline C.R.S +GA3 & 79.80 & 11.28 & 35.21 & 7.05 & 3.35 & 1.46 \\
\hline C.R.S +Mix & 80.62 & 11.97 & 32.11 & 6.68 & 3.05 & 1.19 \\
\hline C.R.S +Mi+ IAA & 82.15 & 13.49 & 29.53 & 6.12 & 2.57 & 0.72 \\
\hline C.R.S +Mi+ F.A & 82.44 & 13.81 & 29.36 & 5.93 & 2.44 & 0.49 \\
\hline C.R.S +Mi+ GA3 & 81.79 & 13.02 & 29.71 & 6.29 & 2.76 & 0.88 \\
\hline L.S.D 5\% & 2.26 & 0.07 & 0.75 & 0.05 & 0.04 & 0.06 \\
\hline
\end{tabular}

\section{C.R.S: compost rice straw}

Mix: mixture of Azotobacter chrococcum, Bacillus circulans

GA3: Gibrellic Acid IAA: Indol Acetic Acid F.A: Fulvic Acid 


\section{DISCUSSION}

Results mentioned above revealed that; an application of compost rice straw under investigation gained less vigor plant growth, total tuber yields and its components on nutrient elements of potato tuber as compared to the application of inorganic fertilizers (N, P and K RD).

These results could be explained on the basis of inorganic fertilizers are soluble forms of soil nutrients, which can be transported much more mobilized and readily than organic manure. Organic manures like CRS release nutrients very slowly to the plants. Therefore, are unable for supply excess required amount of nutrients in the critical period of plant growth. This may be the probable reason for the higher yield produce by the inorganic fertilizer applied for potato.

The present results could be enhanced with those obtained from potato plant by Vasanthakumar (2003),, Choudhury and Saikia . (2005); Chhonkar et al., (2011), and Ouda and Mahadeen (2008).

Inoculation of potato tuber with the mixture of multi strains inoculants in combination with the growth regulators studied and compost rice straw under investigation gave higher value of all parameters than the application of compost rice straw alone. Moreover, such effect of this interaction gave, approximately the same values of inorganic fertilization for all the aforementioned traits. Such effects could be explained on these bases:

- Fulvic acid may have various biochemical effects either at cell wall permeability membrane level or the cytoplasm including increased photosynthesis and respiration rates in plants, enhancing protein synthesis and enhance the uptake of minerals through the stimulation of migrobiological activity(Awad and El-Ghamry 2007).

- The positive effect of yeast may be attributed to its active role in the hydrolysis of carbohydrates and protein and increasing the synthesis of plant growth promoters, especially GA3, IAA and Cytokinin (Dawa et al; 2008 and Manoly and Nasr; 2008)

- The improving effects of the mixed biofertilizers may be attributed to the role played by $\mathrm{N}$-fixing, $\mathrm{P}$ and $\mathrm{K}$ solubilizing bacteria in secreting chelate substances; as organic acids which are important for solubilization of springly soluble inorganic P. Moreover, the hormonal exudates of Azotobacter sp. can modify root growth, morphology and physiology resulting in more absorption of N, P and K from the soil. (Badawy et al; 2003, Saleh et al; 2007, Salim et al; 2007 and Baddour; 2010)

Finally, an application of organic manures in the soil could be enriched soil if it is found feasible and applicable. Therefore, heavy metals will prefer to form chelates with organic compounds. By this way, extractable heavy metals concentrations will be minimized by using organic material (Kara et al; 2004)

\section{CONCLUSION}

Under the same conditions of this investigation it could be recommended that inoculation of potato tuber with the mixture of multi strains inoculants combined with compost rice straw at rate of $15 \mathrm{~m}^{3} \mathrm{fed}^{-1}$ and the 
addition of fulvic acid are considered as the most suitable treatment for realizing the highest economic and safe yield of potato tubers.

\section{REFERENCES}

A.O.A.C (1990). Association Official Analatical Chemists. Official Methods of Analysis. $15^{\text {th }}$ Ed. Washington, DC, USA.

Aksenova, N. P.; T. N. Konstantinova, V. N. Lozhnikova, S. A. Golyanovskaya, and L. I. Sergeeva, (2009). Interaction between day length and phytohormones in the control of potato tuberization in the in vitro culture. Russian J. Plant Physic; 56(4):454-461.

Awad, E., and A. M. El-Ghamry, (2007). Effect of humic acid effective microorganisms (EM) and magnesium on potato in clayey soil. J. Agric. Sci. Mansoura Univ., 32(9): 7629-7639.

Badawy, F. H.; M. M, El Dsouky,; H. S ,Sadiek; and A. A,Abo Baker, 2003. Response of tomato to inoculation with single and multi-strain inoculants of different bacterial species. Assiut Journal of Agricultural Sciences 34(5): 275-286.

Baddour, A.G. (2010) "Effect of bio-fertilization on growth and productivity of tomato plant". M. Sc. Thesis Fac. of Agri. Mans. Univ.

Baddour, A.G., (2014). Ecological studies on potato and onion crops grown under organic farming. Ph.D Thesis Fac. Agric. Mans. Univ. Egypt.

Black, C. A. (1965). Methods of Soil Analysis. Part 2. Amer. Soci. of Agric. [NC] Publisher, Madison, Wisconsin.

Chapman, H. D. and P. F. Pratt (1982) "Methods of Analysis for Soils, Plants and Water. Univ. California, Div. Agric. Sci. Priced Pub. 4034

Chhonkar, D. S.; P. Kumar, and S. K. Shroti, (2011). Efficacy of bio fertilizers in potato (Solanum tuberosum L). Ann.; of Horti; 4(2):197-201.

Choudhury, M. R.; N. C. and A. Saikia (2005). Changes in organic carbon, available N, P2O5 and K2O under integrated use of organic manure, biofertilizer and inorganic fertilizer on sustaining productivity of tomato and fertility of soil. Res. on Crop., 6 (3): 547-550.

Dawa, K. K. ; E. A. A. Tartoura and H. A., Darweesh (2008) "Effect of some different organic and biofertilizers and foliar application treatments on pea crops. J. Agric. Sci. Mansoura Univ., 33 (5) : 3573-3595.

El-Agamy, M. A. (2006). Evalution of some plant residues as organic fertilizers . M. Sc. Thesis, Fac . Agric ., Mansoura Univ ., Egypt.

El-Hamaddy, A.M. ; A.F. Abo-Hadid, Sh. M. Selim ; H.I. El-Kassas and N. Negm (2003). Production of compost from rice straw using different accelerating amendments. I. Environ. Sci. Ain Shams Univ., 6 (3): $112-116$.

Gomez, K. A. and A. A. Gomez (1984). "Statistical Procedures for Agricultural Research". $2^{\text {nd }} E d$. John Wiely and Sons, pp. 680.

Hedge, I.E. and B. T. Hofreiter, (1962). "Carboydrate Chemistry i7 (Eds Whistler R.L. and Be Miller, J.N.) Academic Press New York.

Hesse, P. R. (1971) : "A text Book of Soil Chemical Analysis". Ivan Murry (puplisher), Ltd., London 
Jackson, M. L. (1973). "Soil Chemical Analysis advanced course" Puble. By the auther, Dept. of Soils, Univ. of Wise., Madison 6, Wisconsin, U.S.A.

Kara, E.E; U , Pirlak,. and G. H. ,Ozdilek, (2004): Evaluation of heavy metals $(\mathrm{Cd}, \mathrm{Cu}, \mathrm{Ni}, \mathrm{Pb}$ and $\mathrm{Zn})$ distribution in sowing regions of potato fields in Turkey. Fac. of Economics and Public Administration, Antakya, Hatay, Turkey

Manoly, N. D. and A. A. Nasr (2008). "Response of two cultivars of gladulus to chiken manure in the new reclaimed land. J. Agric. Sci. Mansoura Univ., 33 (12) : 2799-8808.

Mansour, M. A., (2012). Standardization of micronutrients enrichment technique in organic manures and its impact on soil and crop. M.Sc.Thesis Tamil nadu Agric. Univ. India.

Mirzakhani, M., M. R. Ardakani, A. Aeene Band, F. Rejali and A.H. Shirani Rad (2009). Response of Spring Safflower to Co-Inoculation with Azotobacter chroococum and Glomus intraradices Under Different Levels of Nitrogen and Phosphorus. American J. Agric. and Bio. Sci; 4 (3): 255-261.

Moursy, A.A., (2013). Organic fertilization for improving potato production with application of $15 \mathrm{~N}$ - isotope dilution technique. J. Amer. Sci; 9 (10):221-226.

Ouda, B.A. and A.Y. Mahadeen, (2008) Effect of fertilizers on growth, yield, yield components, quality and certain nutrient contents in Broccoli (Brassica olarecia). International J. of Agric. And Biology, 10 (6) : 627-632.

Peters, I.S.; Combs, B.; Hoskins, I., larman; I. kover, M. Watson and N. Wolf (2003). Recommended methods of manure analysis. Univ. of Wisconsin, Cooperative extension Publ., Madison.

Sadasivam, S., and A. Manickam, (1996). Biochemical Methods, $2^{\text {nd }}$ Ed. New age inter. India.

Saleh, M. M., M. Fayza, A. Darwish and M. H. Mona (2007). Effect of different types and levels of organic fertilizers combined with biofertilizers on growth and yield of tomato grown in sandy soil, J. Agric. Sci. Mans. Univ; 32 (7): 5553-5568

Salehi, B.; J. Daneshian, M. R. Ardakani, M. H. Arzanesh, and A. H. S. Rad, (2014). Various source of supply of nitrogen (chemical, animal and biological) on growth, yield and product quality potatoes (Solanum tuberosum L.). Inter. J. Biosci., (IJB); 4(5):232-242.

Salim, E. M.; H. G. Abu El-fotoh and M. H. A. El-mancy (2007). Productivity of tomato plants treated with some biological, organic and inorganic fertilizers. Egypt. J. Soil Sci. 47, No. 3, pp 215-231.

Sadasivam, S., and A. Manickam, (1996). "Biochemical Methods", $2^{\text {nd }}$ Ed. New age inter. India.

Schippers, P. A. (1968). The influence of nitrogen and potassium application on yield and specific gravity of four potato varieties. European Potato J., 11 (1): 88-99.

Shalaan, M. N., (2005). Effect of compost and different sources of biofertilizers on borage plants; Egypt, J. Agric. Rec., 83 (1): 271-284. 
Singh, J. P. (1988). A rapid method for determination of nitrate in soil and plant extracts. Plant and Soil, 110: 137-139.

Vasanthakumar, S. K. (2003). Studies on beneficial endorhizosphere bacteria in solanaceous crop plants. M.Sc. (Agri.) Thesis, Univ. Agric. Sci., Dharwad, Karnataka, India.

Waghmode, H. S.; R. S. Patil and B. S. Pandure (2010). Effect of biofertilizer and gibberellic acid on growth and yield of potato. Asian J. of Horti; $5(1): 228-230$.

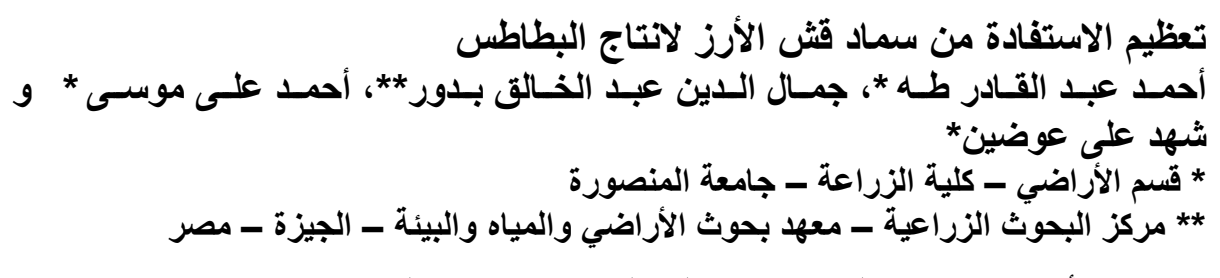

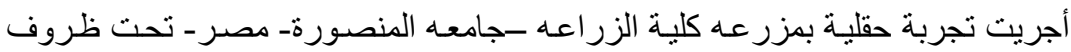

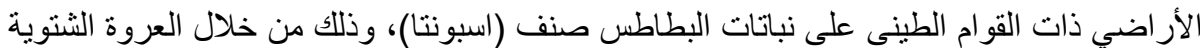

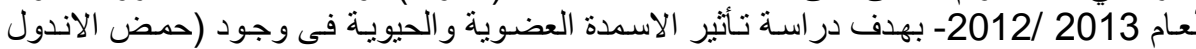

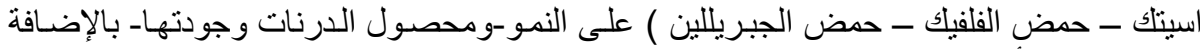

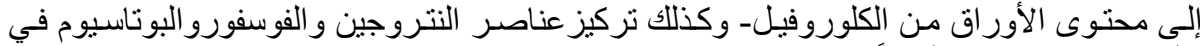

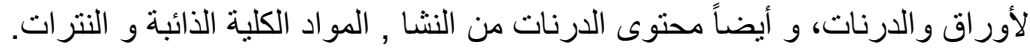
نفذت التجربة في تصميم كامل العشو ائية في 3 مكرر ات مشتملا على 8 معاملات على النحو النحو التالي 1-سماد قش الأرز 2- سماد فش الأرز +مخلوط السماد الحيوى+حمض الاندول 3- سماد قش سمط

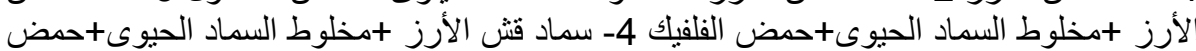

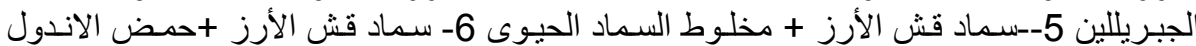

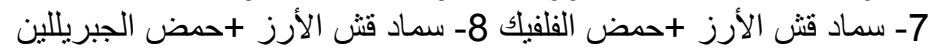

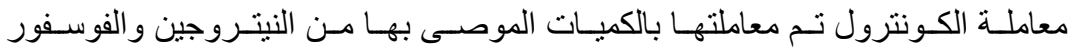
و البوتاسيوم .. أي أن الإجمالي هو 9 معاملات

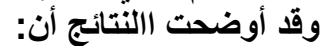

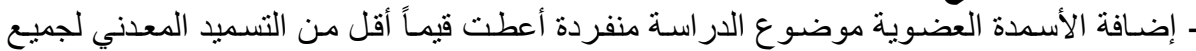

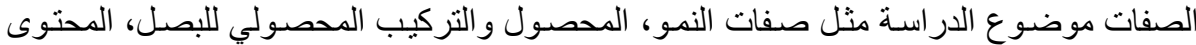

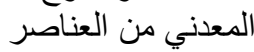

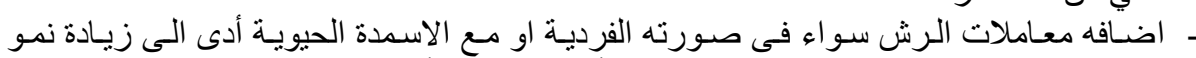

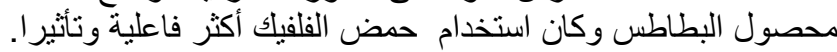

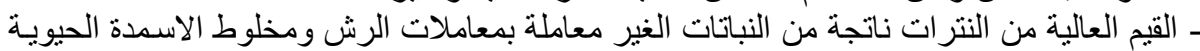

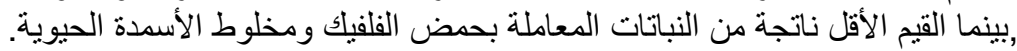

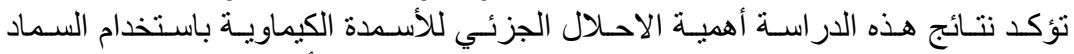

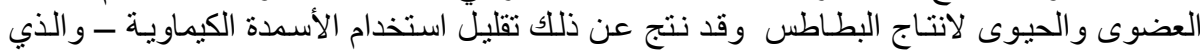
ترتب عليه خفض تكلفة الانتاج وخفض البطن تركيز النترات في الدرنات. 